Research Article

\title{
The histone genes cluster in Rhynchosciara americana and its transcription profile in salivary glands during larval development
}

\author{
Fábio Siviero ${ }^{1}$, Paula Rezende-Teixeira ${ }^{1}$, Alexandre de Andrade $^{1}$, Roberto Vicente Santelli ${ }^{2}$ and \\ Glaucia Maria Machado-Santelli ${ }^{1}$ \\ ${ }^{1}$ Departamento de Biologia Celular e Desenvolvimento, Instituto de Ciências Biomédicas, \\ Universidade de São Paulo, São Paulo, SP, Brazil. \\ ${ }^{2}$ Departamento de Bioquímica, Instituto de Química, Universidade de São Paulo, São Paulo, SP, Brazil.
}

\begin{abstract}
In this work we report the characterization of the Rhynchosciara americana histone genes cluster nucleotide sequence. It spans 5,131 bp and contains the four core histones and the linker histone $\mathrm{H} 1$. Putative control elements were detected. We also determined the copy number of the tandem repeat unit through quantitative PCR, as well as the unequivocal chromosome location of this unique locus in chromosome A band 13. The data were compared with histone clusters from the genus Drosophila, which are the closest known homologues.
\end{abstract}

Keywords: Rhynchosciara, histone cluster, Sciaridae, codon usage.

Received: November 24, 2015; Accepted: February 16, 2016.

\section{Introduction}

Rhynchosciara americana is a dipteran belonging to the family Sciaridae, commonly known as dark-winged fungus gnats. These are known for its exuberant polytene chromosomes and developmentally regulated DNA amplification loci present in several tissues, the so-called DNA puffs. $R$. americana has been the object of research since the 1950s (Nonato and Pavan, 1951), but besides the wellknown physiology of its polytene chromosomes and their puffs (Santelli et al., 1991, 2004; Frydman et al., 1993, Penalva et al., 1997), the underlying overall molecular biology and evolution are poorly understood.

In $R$. americana salivary glands, the last cycle of DNA replication encompasses a gene amplification phenomenon generating DNA puffs (Breuer and Pavan, 1955; Ficq and Pavan, 1957; Rudkin and Corlette, 1957). This well-documented polyteny cycle lasts for 5 or 6 days. (Machado-Santelli and Basile,1973, 1975). Due to its long duration, it is possible to precisely follow the replication and transcription processes. However, several structural characteristics of these unusual chromosomes present in Sciaridae are still unknown, such as the amplification control elements.

We started to focus on the histone class of genes as an approach to better understand chromatin structure aspects

Send correspondence to Glaucia Maria Machado-Santelli. Departamento de Biologia Celular e Desenvolvimento, Instituto de Ciências Biomédicas (ICB1), Universidade de São Paulo, Av. Lineu Prestes, 1524, Cidade Universitária, 05509-000 São Paulo, SP, Brazil. E-mail: glaucia.santelli@gmail.com in the salivary glands of Rhynchosciara, and to provide molecular markers for this species. The replication-dependent histones and their variants are common chromatin components of great interest because of their involvement in the modulation of the chromatin transcriptional status and with the replication process.

Data from several laboratories have implicated regulatory regions of the histone genes as targets for factors acting under the control of the Cdk2/cyclin E complex (Ewen, 2000). In mammals, the factor NPAT, identified as substrate of that complex, is a linker element between cell cycle regulators and histone gene transcriptional activation (Zhao et al., 2000; Gao et al., 2003). Identification of Cajal bodies (CB) participating in this process, as well as the Stem Looping Binding Protein (SLBP), brought new elements to the understanding of the cell cycle-dependent activation of the transcriptional program (G1-S transition) (Marzluff, 2005).

Histones, as the main chromatin organizing proteins, are extremely conserved among eukaryotes. Due to their slow rate of modification through evolution they became landmarks for phylogenetic analysis of distant organisms (Thatcher and Gorovsky, 1994). Usually, histone genes are arranged in two forms: (1) in a cluster containing the five histone genes repeated in tandem several times, such as in Drosophila and Chironomus, or (2) dispersed in the genome forming incomplete clusters or as single, isolated genes, like in humans (Matsuo and Yamazaki, 1989; Nagoda et al., 2005; Hankeln and Schmidt, 1991). 
Previous studies have identified the $R$. americana histone gene cluster using a $D$. hydei probe, and semiquantitative Southern blotting experiments were able to estimate its copy number as approximately 150 tandemly arranged units. Fluorescent in situ hybridization analysis localized its chromosomal site in region 13 of chromosome A, near the pericentromeric region (Santelli et al., 1996).

To advance the study of $R$. americana histone genes, we now report the complete sequence of the $R$. americana histone gene cluster and the description of its canonical and putative regulatory elements. The data are also compared with counterparts in the genus Drosophila genus, due the phylogenetic proximity between the two genera.

\section{Material and Methods}

\section{Library construction}

A recombinant phage $\lambda$ DASHII (Stratagene) - RaHis (Santelli et al., 1996) previously isolated using a Drosophila hydei histone probe was cut with NotI restriction enzyme and the isolated insert was extracted with phenol. Approximately $50 \mu \mathrm{g}$ of this DNA was sheared using the nebulization method (shotgun strategy) and fragments were separated in low melting point agarose and size selected $(1.0-1.5 \mathrm{~kb})$. Approximately $2 \mu \mathrm{g}$ of DNA were then treated with Klenow/PNK enzyme (Amersham/Pharmacia) in a blunting reaction and cloned in pUC18 (Sigma) using T4 DNA Ligase (Gibco).

\section{Sequencing and assembly}

Recombinant $E$. coli $\mathrm{DH} 5 \alpha$ selected by IPTG/XGAL grown in $1 \mathrm{~mL}$ of Circle Grow (USB) medium were pelleted $(2,200 \mathrm{x} \mathrm{g}$ for $10 \mathrm{~min})$ in microplates, following $\mathrm{SDS} / \mathrm{NaOH}(10 \% / 0.2 \mathrm{M})$ lysis and potassium acetate $(3 \mathrm{M})$ debris precipitation. The lysate was filtered using a MAGV N22 filter plate (Millipore). The plasmid solution was precipitated with isopropanol, washed with ethanol $80 \%$ and finally suspended in $30 \mu \mathrm{L}$ of $10 \mathrm{mM}$ Tris. Sequencing reactions were performed in a PCR GeneAmp 9700 thermocycler (Perkin Elmer), using BigDye terminator technology $\left(96^{\circ} \mathrm{C}\right.$ for $1 \mathrm{~min}, 35$ cycles of $96^{\circ} \mathrm{C}$ for $20 \mathrm{~s}, 50^{\circ} \mathrm{C}$ for $1 \mathrm{~min}$ and- $60^{\circ} \mathrm{C}$ for $4 \mathrm{~min}$ ). The samples were precipitated with ethanol/Na acetate (3M) supplemented with glycogen $(1 \mathrm{~g} / \mathrm{L})$ and run in an ABI 377 automatic sequencer (Applied Biosystems).

The electropherograms were analyzed and assembled using Phred, Phrap and Consed software packages (Ewing et al., 1998; Ewing and Green, 1998; Gordon et al., 1998). We adopted the standard Phrap assembly parameters and considered a sequence as of high quality if it had at least 150 contiguous bp with quality $\geq 20$ inferred by Phred. The error estimated by the Phred/Phrap/Consed suite for this assembly was $1 / 10,000 \mathrm{bp}$.

\section{Sequence analysis}

The initial analyses were carried out through Genscan software (Burge and Karlin, 1997), posterior sequence comparisons, dot-maps and pattern searches were performed with Emboss packages (Rice et al., 2000). ClustalX was utilized to build alignments (Thompson et al., 1997).

Promoter prediction was made with the Neural Network Promoter Prediction service (http://www.fruitfly.org/seq_tools/promoter.html) (Reese, 2001). CodonW software (Peden, 1999) (http://codonw.sourceforge.net/) was used to generate codon usage tables.

The sequences of histone gene clusters from Drosophila hydei (X17072), Drosophila melanogaster (X14215) and Chironomus thummi (X56335) were downloaded from NCBI and used for comparisons.

\section{Quantitative PCR}

The repeat unit copy number was estimated through real time PCR. The primers H2Aq1 (TTTCGGCAAT AGGACTGCTT) and H2Aq2 (ATTGGAATTGGCTGG TAACG) were designed to amplify a histone cluster fragment and RaCHAP-Q1 (GCTTAACAAATGAATCA GTC) and RaCHAP-Q2 (ACTCATTAAACAAAAG GTCA) to amplify a T-complex Chaperonin 5 fragment (Rezende-Teixeira, personal communication), a gene present in single copy in Drosophila. The SYBR Green reactions were assembled as instructed by the kit manufacturer (ABgene), with template DNA extracted from testis of adult flies according to Rezende-Teixeira et al. (2012). Amplification rates were estimated considering Chaperonin as a single copy gene also in Rhynchosciara, using the mathematical method described by Pfaffl (2001).

RNA extractions from salivary glands were performed as described in Rezende-Teixeira et al. (2009), and absolute quantitative RT-PCR assays were performed as described by the kit manufacturer (AgPath-ID One-Step RT-PCR, Life Technologies)

The primer set used was: RaH1q1 CGTCCGGTT CATTCAAACTT; RaH1q2 TCACTGAGCCAGCCTTC TTT; RaH3q1 AATTCGTCGCTACCAAAAGAG; RaH3q2 CAGAGCCATAACCGCTGAACT; RaH4q1 ATTACGAAACCAGCCATTCG; RaH4q2 ACCTCCGA AACCGTACAATG; RaH2Aq1 TTTCGGCAATAGGA CTGCTT; RaH2Aq2 ATTGGAATTGGCTGGTAACG; RaH2Bq1 AGAAACGCAAGCGTAAGGAA; RaH2Bq2 TGGTGATGGTCGATCGTTTA.

The experiments were performed in triplicate and dilutions of the cloned histone cluster itself served to establish the reference curve (all the $5.1 \mathrm{~kb}$ cloned in pBluescript KS, Stratagene). The primers listed above were designed to produce amplification products containing amplicons of 100-200 bp, all of which were specific products, which was especially important in the case of histone RaH3, which shares many similarities with RaH3.3 (Siviero et al., 2006). 
The amplification efficiencies were determined for all primer pairs (RaH1: 100\%; RaH3: 99\%; RaH4: 99\%; $\mathrm{RaH} 2 \mathrm{~A}$ : 100\%; RaH2B: 99\%; RaCHAP: 99\%).

\section{In situ hybridization}

Salivary gland chromosomes fixed with ethanolacetic acid (3:1) were squashed in $45 \%$ acetic acid. The coverslips were removed by freezing the slides on dry ice. The preparations were then washed in PBS, denatured for 3-5 minutes in $\mathrm{NaOH}(0.07 \mathrm{M})$, washed in a series of alcohol and dried. Probes were labelled using the dUTP-digoxigenin Random-primer kit (Roche) according to manufacturer instructions and denatured by heating just before the hybridisation step. The hybridized probes were revealed by fluorescein labelled anti-digoxigenin serum (Roche) and the chromosomes were counterstained with propidium iodide. The preparations were analysed in a laser scanning confocal microscope, LSM-510 (Zeiss), and were considered positive the regions labelled in most of the chromosome optical sections.

\section{Results and Discussion}

\section{General sequencing results}

A large insert of the histone gene cluster repeat was sub-cloned from a previously isolated recombinant phage and sequenced by shotgun technique. The histone repeat unit in $R$. americana has 5,131 bp (GenBank accession number: AF378198), containing single sites for different restriction enzymes: for $E c o \mathrm{RV}$ in the RaH1-RaH3 spacer; for HindIII in the RaH3 coding region, and for $P v u \mathrm{I}$ in the RaH2B portion (Figures 1 and 2). As commonly observed in other histone clusters, the intergenic spacers are AT-rich. The orientation of the individual histone genes is similar to those in Drosophila melanogaster and Drosophila hydei, except for the $\mathrm{H} 1$ gene (Figures 1 and 2). The R. americana cluster also shares other similarities with its $D$. hydei homologue: like its length, which is only 22 bp shorter, a CG content, $37 \%$ for $R$. americana and $38 \%$ for $D$. hydei (Table 1), and a strong nucleotide identity in the coding regions (Table 2).

Through quantitative real time PCR it was possible to obtain an estimate of 159 copies of the histone cluster unit ( \pm 24 Median Absolute Deviation) in the haploid genome of $R$. americana, which is similar with observations for the genus Drosophila (110-150 copies).

\section{5' UTR elements}

Among the predicted promoter regions, canonical TATA-boxes were found only upstream of the RaH3, RaH4 and RaH2B genes, while $\mathrm{RaH} 1$ and $\mathrm{RaH} 2 \mathrm{~A}$ presumptive promoters have TATA-like sequences. In the putative leader sequences of the genes $\mathrm{RaH} 1, \mathrm{RaH} 3, \mathrm{RaH} 4$ and RaH2B, the element AGTGAA (or AGTG-like), was found near the start codon of $\mathrm{RaH} 3$ and $\mathrm{RaH} 2 \mathrm{~B}$, and in the promoter region of RaH1, $\mathrm{RaH} 4$ and $\mathrm{RaH} 2 \mathrm{~B}$. As observed in D. hydei (Kremer and Hennig, 1990), only RaH3 showed an AGTGA block near the start codon (Figure 1). These AGTG-like elements were suggested to have a specific function related to histone expression in the genus Drosophila (Matsuo and Yamazaki, 1989; Matsuo, 2003). This hypothesis is now reinforced by the presence of the same AGTG-like elements in the $R$. americana histone repeat unit. The present data actually suggest that the role of these elements can be extrapolated for the Sciaridae family as a whole.

\section{3' UTR elements}

In the 3' untranslated region (3' UTR) of each histone gene one palindrome or near-palindrome sequence block was found. These are the hairpin formers (Figures 1 and 3) involved with the regulation of mRNA processing of the cell-cycle dependent histone genes (Birchmeier et al., 1982). The inverted repeat present in RaH1 gene is more divergent when compared with the palindromes of the other core histones genes, as was also observed in $D$. melanogaster and D. hydei (Kremer and Hennig, 1990). The RaH1 distance from the stop codon (48 bp) is only slightly longer than the one observed in the core histones genes (RaH3: 23 bp; RaH4:40 bp; RaH2A:44 bp; RaH2B: $39 \mathrm{bp}$ ), and is almost half the distance when compared to the Drosophila homologs.

Interestingly, with the exception of RaH4, these inverted repeats found in $R$. americana can be grouped by similarity with their homologs in the Drosophila genus (Figure 3), indicating a possible common origin of these elements. The palindromes for $\mathrm{H} 3$ histones from $R$. americana and $\mathrm{H} 3 / \mathrm{H} 4$ from D. melanogaster and D. hydei are a perfect match. The inverted repeat from $\mathrm{RaH} 4$ is imperfect, it is $1 \mathrm{bp}$ shorter in the $5^{\prime}$ extremity and similar to the palindromes found in the $\mathrm{H} 2 \mathrm{~B}$ genes of these three insects. Identity between hairpins of the $\mathrm{H} 4$ and $\mathrm{H} 2 \mathrm{~B}$ genes is also observed in Chironomus thummi, which is only a single base different from the correspondent hairpin in Rhynchosciara.

Interestingly, the element $\mathrm{CAA}(\mathrm{T} / \mathrm{G}) \mathrm{GAGA}$, which is common in the genus Drosophila and is related to the binding of snRNA, or other similar consensus blocks were not found in R. americana (Mowry and Steitz, 1987; Soldati and Schumperli, 1988). Further research will thus be needed to determine whether $R$. americana is able to use another sequence to bind snRNAs, or whether it has a mechanism for mRNA maintenance which is somewhat different from the usual one.

Poly-A signals were predicted for the five histone genes, but the prediction algorithm scores were too low for $\mathrm{RaH} 1, \mathrm{RaH} 3$ and $\mathrm{RaH} 2 \mathrm{~A}$, so they will not be considered here. The poly-A signals found in $\mathrm{RaH} 4$ and $\mathrm{RaH} 2 \mathrm{~B}$ corresponded to the consensus sequence AATAAA, however no 3' U-rich regions were observed, even putatively down- 


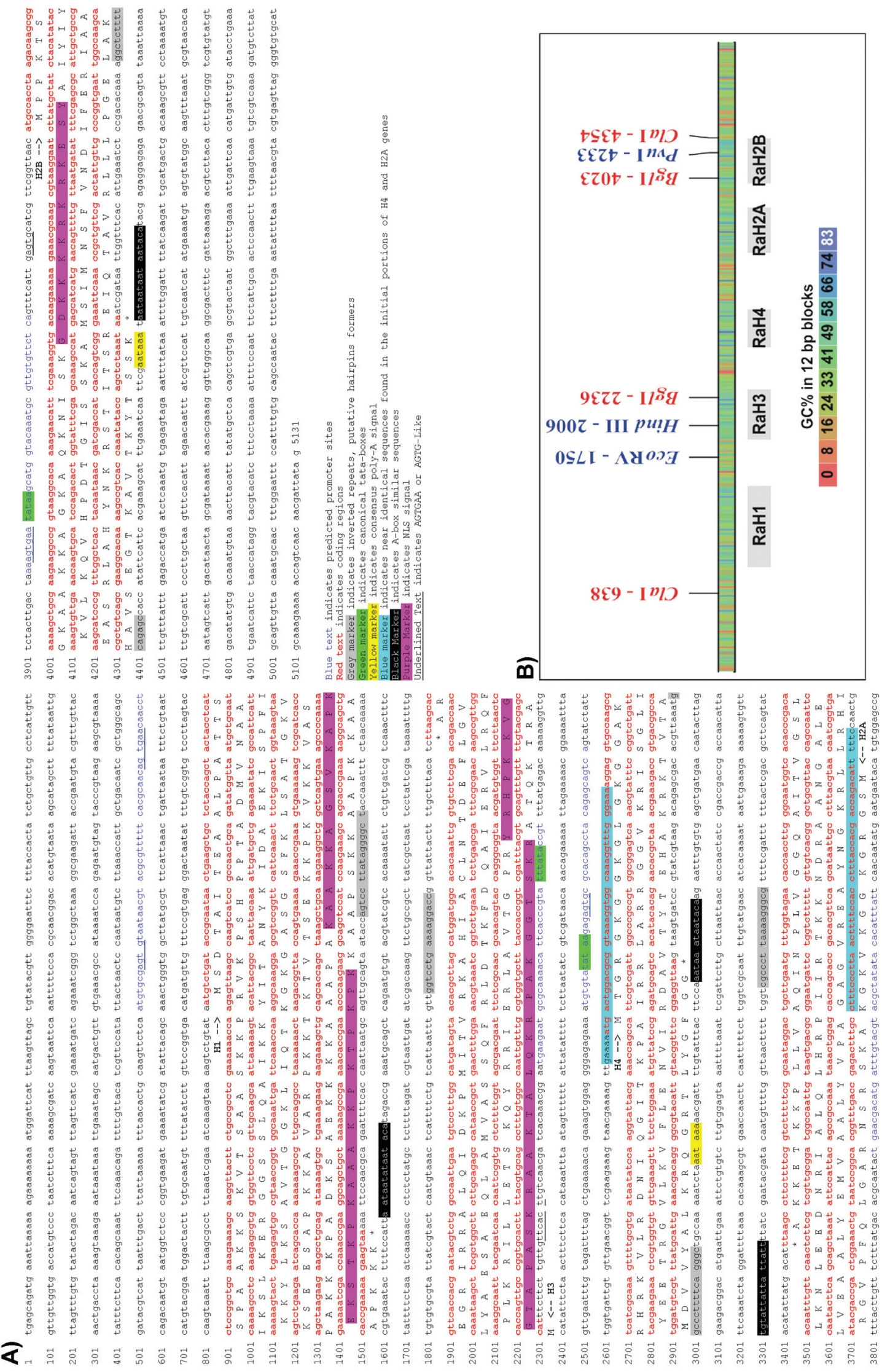

Figure 1 - The Rhynchosciara americana histone genes. A) Repeat unit sequence, highlighted are putative control elements. B) Restriction map and GC content. 


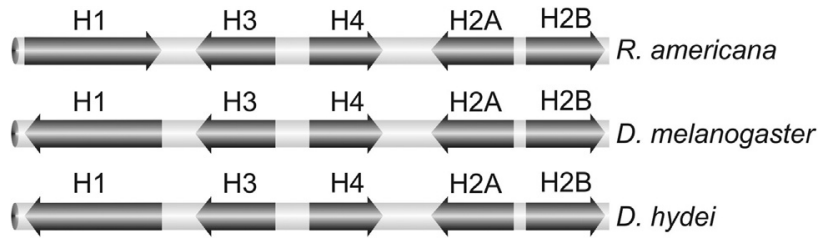

Figure 2 - Orientation of histone genes in clusters from different organisms.

stream CA poly-adenylation sites being present (Manley and Takagaki, 1996). In the annelid C. variopedatus, canonical poly-A signals were found for the five genes in the histone cluster (del Gaudio et al., 1998). The authors hypothesized that the presence of these termination signals in present in all ancestral histones was substituted during the evolution by the hairpin structure, which corresponds to the observation that these signals are unequally distributed among the histone genes in the Rhynchosciara cluster. Double termination signals were reported for the H2B, H3 and $\mathrm{H} 4$ genes in D. melanogaster by Akhmanova et al. (1997). Based on the present data, however, we cannot conclude whether these poly-adenylation signals are actually functional in $R$. americana.

\section{Other interesting elements}

Strikingly, the genes RaH4 and RaH2A share almost the same 44 bases region in the 5 ' portion ( $84 \%$ identity), starting 5 bp upstream of the start codon (GAAAA) and encompassing the coding segment for the first 13 amino acids, which are, as expected, also very similar (Figure 1A). This identity level is not observed in the same portions of the clusters from $D$. melanogaster, D. hydei or C. thummi.
These 44 bases, including the 5 non-coding base pairs, may reflect the a common origin of these genes, or at least the same origin of this initial domain.

Other noteworthy elements are two identical sequence blocks in the 3' UTR of RaH2A and RaH2B (AATAATAATAATACA), and two similar blocks in the 3' UTR of RaH4 (AAATAAATAATACA) and RaH1 (AATAATATAATACA), all positioned 38-45 bp downstream of the palindromes. These elements resemble A-boxes, and their position suggests that they may play a role in mRNA termination.

\section{Coding regions}

Codon usage determined for the histone genes of $R$. americana (Tables S2-S7) shows several points of similarity with the histone codon usage for $D$. hydei. A few differences lay on the Rhynchosciara preferential codons: UUG (Leu), CCA and CCG (for Pro), AAA (Lys), CAA (Gln) and GGU (Gly). The only stop codon used in these genes is UAA.

The GC content in the coding regions of the Rhynchosciara histone gene cluster ranges from $44.2 \%$ (RaH1) to $47.9 \%$ (RaH4) with a mean value of $45.9 \%$ (Supplementary material, Tables S2-S7). These values are lower than those observed in D. melanogaster (mean 51.4\%) and D. hydei (mean $48.9 \%$ ). The GC content at the $3^{\text {rd }}$ codon bases (GC3s) is also much lower than that observed in the genus Drosophila, 38.4\% (average) (Table 3 and Table $\mathrm{S} 1)$; the lowest GC3s is $34.6 \%$ in the RaH3, lower than the GC3s from histone $\mathrm{H} 3$ of 16 Drosophila species analyzed by Matsuo (2003). In that study the author proposes that a reduction in the population size of a common ancestor of $D$.

Table 1 - Nucleotide frequencies of histone repeat unit of R. americana, D. hydei, D. melanogaster (L unit) and C. thummi.

\begin{tabular}{lcccc}
\hline Nucleotide & $\begin{array}{c}\text { R. americana } \\
(5131 \mathrm{bp})\end{array}$ & $\begin{array}{c}\text { D. hydei } \\
(5153 \mathrm{bp})\end{array}$ & $\begin{array}{c}\text { D. melanogaster } \\
\text { (5041bp) }\end{array}$ & $\begin{array}{c}\text { C. thummi } \\
(6271 \mathrm{bp})\end{array}$ \\
\hline Adenine (A) & $32.7 \%$ & $30.3 \%$ & $28.4 \%$ & $35.4 \%$ \\
Cytosine (C) & $19.2 \%$ & $18.9 \%$ & $20.2 \%$ & $15.6 \%$ \\
Guanine (G) & $19.5 \%$ & $19.1 \%$ & $20.1 \%$ & $16.7 \%$ \\
Thymine (T) & $28.6 \%$ & $31.7 \%$ & $31.3 \%$ & $32.3 \%$ \\
\hline
\end{tabular}

Table 2 - Nucleotide identities between R. americana and other Diptera histone coding regions and comparison among histone proteins from these organisms, denoting identity and similarity. (Dm $-D$. melanogaster, $\mathrm{Dh}-D$. hydei, $\mathrm{Ct}-C$. thummi)

\begin{tabular}{lccccc}
\hline & RaH1 x H1 & RaH2A x H2A & RaH2B x H2B & RaH3 x H3 & RaH4 x H4 \\
\hline Dm (Nucleotide) & $49 \%$ & $79 \%$ & $80 \%$ & $80 \%$ & $78 \%$ \\
Dh (Nucleotide) & $48 \%$ & $82 \%$ & $80 \%$ & $84 \%$ & $82 \%$ \\
Ct (Nucleotide) & $58 \%$ & $82 \%$ & $79 \%$ & $83 \%$ & $85 \%$ \\
Dm (Protein) & $45 \%(63 \%)$ & $99 \%(100 \%)$ & $98 \%(99 \%)$ & $99 \%(100 \%)$ & $100 \%$ \\
Dh (Protein) & $46 \%(65 \%)$ & $100 \%$ & $98 \%(99 \%)$ & $100 \%$ & $100 \%$ \\
Ct (Protein) & $38 \%(54 \%)$ & $97 \%(99 \%)$ & $93 \%(96 \%)$ & $100 \%$ & $100 \%$ \\
\hline
\end{tabular}


A)

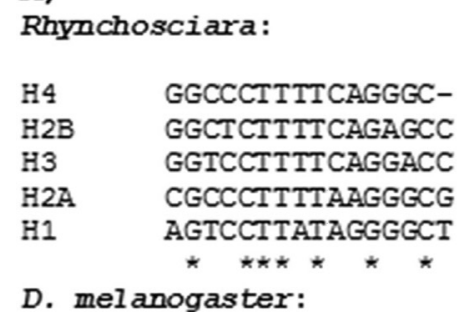

H3 GGTCCTTTTCAGgaCC H4 GGTCCTTTTCAGGACC

H2B GGCCCTTTTCAGGGCC

H2A CGTCCTTTTCAGGACG

H1 AGTCCTTTTCAGGGCT

D. hydei:

H4 GGTCCTTTTCAgGaCC

H2B GGCCCTTTTCAGGGCC

H3 GGTCCTTTTCAGGACC

H1 AGTCCTTTTCAGGACT

H2A CGUCCTTTTCAGGACG
B)

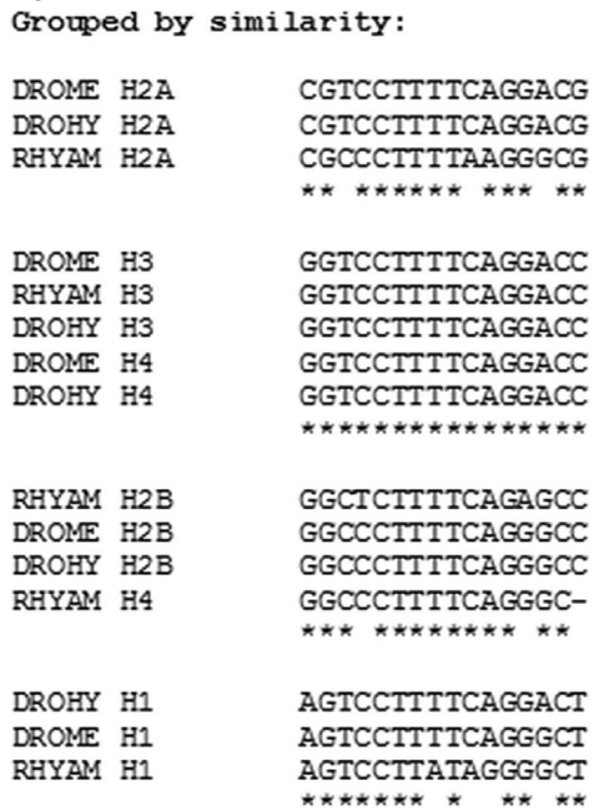

Figure 3 - Comparison among hairpins forming inverted repeats from R. americana, D. hydei and D. melanogaster.

Table 3 - Bases distribution in the $3^{\text {rd }}$ codon position and GC content of the coding region and in the $3^{\text {rd }}$ codon base.

\begin{tabular}{lcccccc}
\hline & T3s & C3s & A3s & G3s & GC3s & GC \\
\hline H1 & 0.3893 & 0.1946 & 0.4058 & 0.2412 & 0.352 & 0.442 \\
H3 & 0.4762 & 0.2381 & 0.3136 & 0.1892 & 0.346 & 0.473 \\
H2A & 0.3980 & 0.2449 & 0.3271 & 0.2376 & 0.393 & 0.468 \\
H2B & 0.3556 & 0.3889 & 0.2913 & 0.2447 & 0.483 & 0.450 \\
H4 & 0.4048 & 0.2619 & 0.3295 & 0.1951 & 0.376 & 0.479 \\
Average of genes & 0.4049 & 0.2567 & 0.3451 & 0.2249 & 0.384 & 0.459 \\
\hline
\end{tabular}

hydei and D. americana may have relaxed the selective pressure, increasing the frequency of substitutions at the $3^{\text {rd }}$ codon bases for A and T. However, the intriguingly low GC3s content in Rhynchosciara suggests two possible explanations: 1) the genera Rhynchosciara and Drosophila would share a common ancestor, so the same conditions of selection pressure and relaxation that occurred for $D$. hydei and $D$. americana could affect $R$. americana; or 2) since Rhynchosciara belongs to an ancient branch divergence in Diptera, the common ancestor could already have had a low GC3s content at this locus.

\section{Histone proteins}

In other organisms, several motifs and domains were identified in histone DNA and protein sequences, such as promoters, nuclear localization signals (NLS) and functional histone domains. In $R$. americana, at least for $\mathrm{H} 1, \mathrm{H} 3$ and $\mathrm{H} 2 \mathrm{~B}$, we have identified NLS motifs, and the linking motif of $\mathrm{H} 1$ fits all the parameters assumed for others sequences. As expected, all the core characteristic domains for this class of proteins (histone domain/InterPro Search) are present and are nearly identical when compared to Drosophila and Chironomus.

\section{Localization of the histone repeat in Rhynchosciara}

To determine the possible existence of other histone clusters spread across the $R$. americana chromosomes, fluorescent in situ hybridization assays were performed. These assays evidenced a single positive band in region 13 of chromosome A when using the repeat unit as probe. The same band was seen under a wide range of stringency conditions (Figure 4). This result suggests the inexistence of other clusters for the replication-dependent histone genes, as is also the case in D. virilis (Nagel and Grossbach, 2000) and in D. americana (Nagoda et al., 2005). This puts in evidence a strong synteny for the histone gene cluster in the genus Rhynchosciara, as the same locus was reported to contain the histone cluster in $R$. baschanti and $R$. hollaenderi (Stocker and Gorab, 2000). Southern blot analysis of DNA from salivary glands from a recently discovered species, Rhynchosciara sp., showed a unique HindIII $5.1 \mathrm{~kb}$ band labeling (result not shown) that corresponds to 

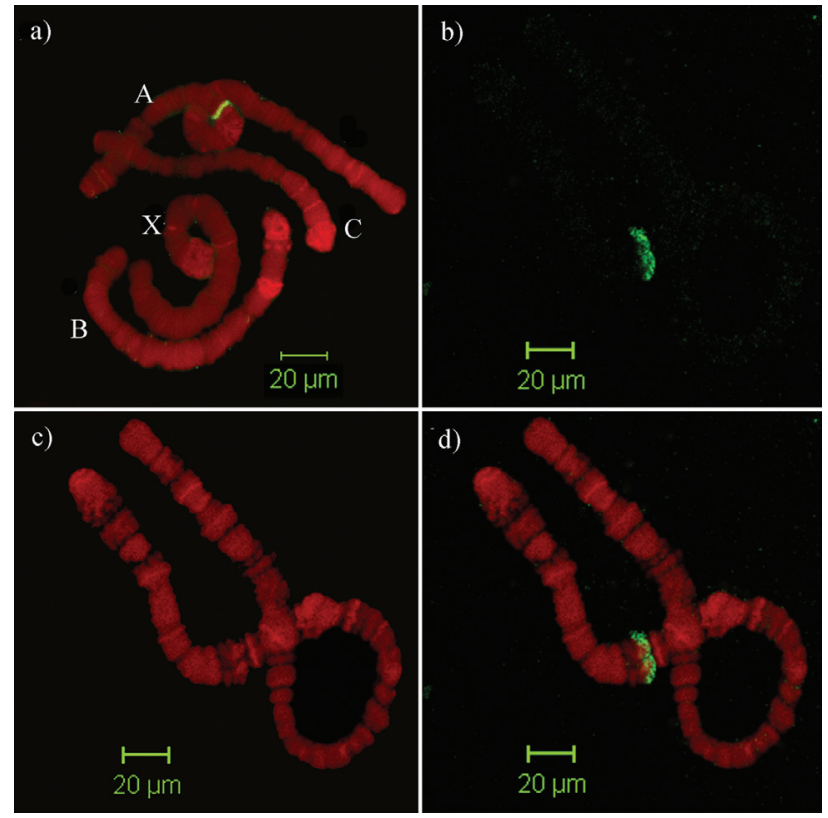

Figure 4 - In situ hybridization using histone gene repeats as probe labeled with digoxigenin and revealed by a FITC-antidigoxigenin antibody, indicating a single locus in region 13 of chromosome A. A) four chromosomes from a single salivary gland cell. B) Split image of chromosome A showing labeled region A13. C) Chromosome counterstained with propidium iodide. D) merged images.

the size of the $R$. americana repeat. The new Rhynchosciara species was collected in Ubatuba, SP, and its proper description is in progress (Machado-Santelli G.M., unpublished results).

These results indicate that the unique cluster present in the $13 \mathrm{~A}$ locus, containing all the replication-dependent histone genes, may be a common feature among Rhynchosciara species.

\section{Transcription profile in salivary glands}

To analyze the role of these canonical histones during polytene chromosome development, we determined the transcriptional profile in salivary glands of each of the histone genes present in the cluster of Rhynchosciara. The expression levels were measured by absolute quantification of the respective transcripts. We believe that this information can contribute to a better understanding of chromatin alterations occurring during the gene amplification or polytenization processes, and to the understanding the role of histone variants such as $\mathrm{RaH} 3.3$ detected in this tissue (Siviero et al., 2006).

The expression profiles (Figure 5) show that all histones have greatly increased transcription levels from the moment on when cocoon spinning starts. This was expected, since this period encompasses the last polytenization cycle and the beginning of gene amplification in certain puffs.

Interestingly, the RaH4 mRNA levels were much higher than those for the other histone genes at all stages an-
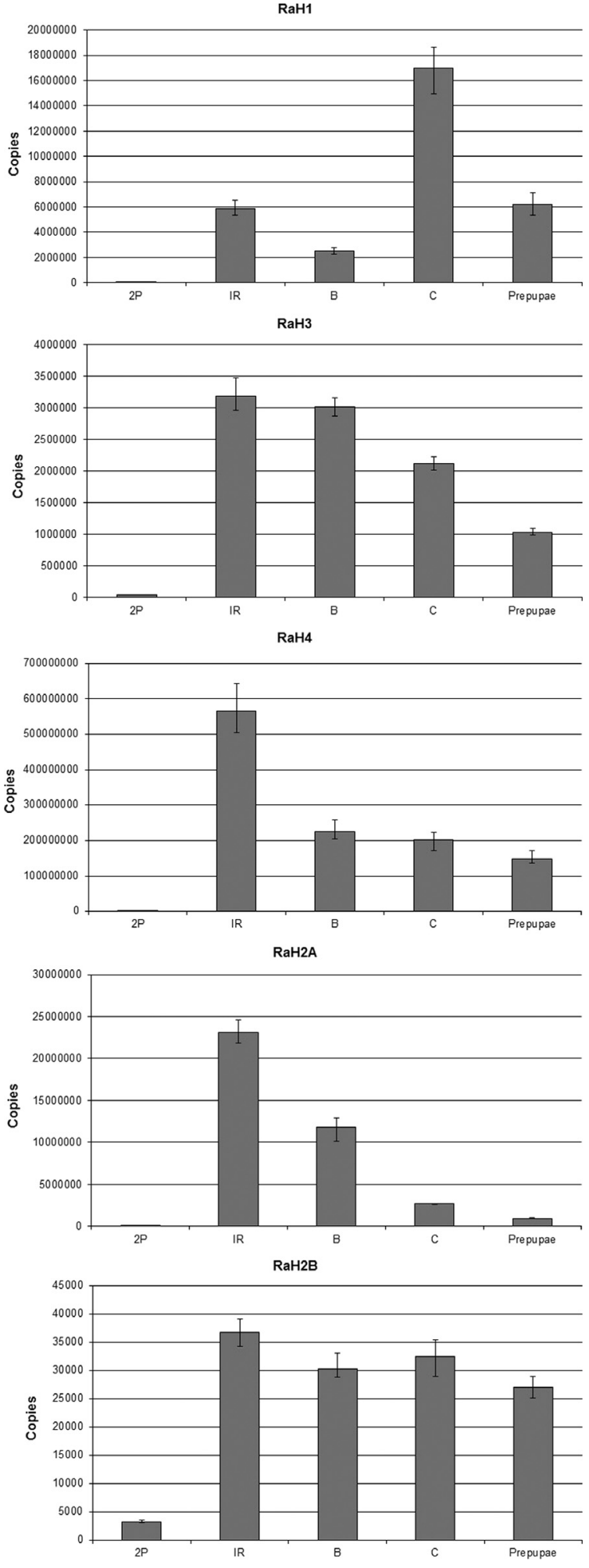

Figure 5 - Transcription profiles of the Rhynchosciara americana canonical histone genes during larval development through absolute quantification. The vertical axis shows transcript numbers for each developmental period: $2 \mathrm{P}$ - second period of the fourth Instar; IR $-3^{\text {rd }}$ period of the fourth instar, corresponding to initial cocoon spinning; $\mathrm{B}-4^{\text {th }}$ period of the fourth instar, corresponding to Puff $2 \mathrm{~B}$ formation; $5^{\text {th }}$ period of fourth instar corresponding to Puff $3 \mathrm{C}$ formation; and $6^{\text {th }}$ period of fourth instar corresponding the prepupal stage. Shown are means and standard errors of the mean for the triplicate samples. 
alyzed. This may reflect an increased consumption of protein due to a higher turnover, or it may be a consequence of a shorter half-life of this mRNA, since in Rhynchosciara this gene has an imperfect hairpin in its 3' UTR portion.

The lowest detected mRNA levels were observed for $\mathrm{RaH} 2 \mathrm{~A}$ and $\mathrm{RaH} 2 \mathrm{~B}$, which may be a direct consequence of the use of other variants of these proteins (Park and Luger, 2008; Lindner, 2008), very common in other organisms, or can be caused by a longer half-life of the mRNA.

While the nucleosomal histones (core histones) presented a transcription peak in the initial cocoon-spinning period (IR), with a consequent decrease in other stages, the Histone RaH1 showed a higher level of transcription in the period of 3C puff expansion. Even in prepupae, the RaH1 levels were higher than during IR. This pattern of transcription may be related to chromatin modifications necessary for gland histolysis and later metamorphosis, such as higher chromosome condensation (Brandão et al., 2014).

\section{Final remarks}

The characterization of the $R$. americana histone gene cluster adds new insights to this evolutionarily and genomically poorly studied system. These data indicate that $R$. americana has a single cluster of the five histone genes repeated approximately 159 times. Sequencing and analysis of the histone clusters from the other known Rhynchosciara species ( $R$. baschanti, R. hollaenderi, $R$. milleri, $R$. papaveroi and $R$. $s p$ ) will now be greatly facilitated and could introduce important molecular data for an evolutionarily much more ancient dipteran genus than Drosophila, possibly providing relevant data on the evolution of the Diptera branch as a whole.

\section{Acknowledgments}

The authors thank L. D. Navarro-Cattapan for library construction, CAPES and CNPq for fellowships to the authors are acknowledged. This work was financially supported by FAPESP (Grants: 03/13206-4; 2016/10428-6) and CNPq (310908/2013-2)

\section{References}

Akhmanova A, Miedema K, Kremer H and Hennig W (1997) Two types of polyadenated mRNAs are synthesized from Drosophila replication-dependent histone genes. Eur J Biochem 244:294-300.

Birchmeier C, Grosschedl R and Birnstiel ML (1982) Generation of authentic 3' termini of an H2A mRNA in vivo is dependent on a short inverted DNA repeat and on spacer sequences. Cell 28:739-745.

Brandão A dos S, do Amaral JB, Rezende-Teixeira P, Hartfelder K, Siviero F and Machado-Santelli GM (2014) Cell death and tissue reorganization in Rhynchosciara americana (Sciaridae: Diptera) metamorphosis and their relation to molting hormone titers. Arthropod Struct Dev 43:511-522.
Breuer ME and Pavan C (1955) Behavior of polytene chromosomes of Rhynchosciara angelae at different stages of larval development. Chromosoma 7:341-386.

Burge C and Karlin S (1997) Prediction of complete gene structures in human genomic DNA. J Mol Biol 268:78-94.

del Gaudio R, Potenza N, Stefanoni P, Chiusano ML and Geraci G (1998). Organization and nucleotide sequence of the cluster of five histone genes in the polychaete worm Chaetopterus variopedatus: First record of a H1 histone gene in the phylum Annelida. J Mol Evol 46:64-73.

Ewen ME (2000) Where the cell cycle and histones meet. Genes Dev 14:2265-2270.

Ewing B and Green P (1998). Base-calling of automated sequencer traces using Phred, 2. Error probabilities. Genome Res 8:186-194.

Ewing B, Hillier LD, Wendl MC and Green P (1998) Base-calling of automated sequencer traces using Phred, 1. Accuracy assessment. Genome Res 8:175-185.

Ficq A and Pavan C (1957) Autoradiography of polytene chromosomes of Rhynchosciara angelae at different stages of larval development. Nature 198:983-984.

Frydman HM, Cadavid EO, Yokosawa J, Silva F, Navarro-Cattapan LD, Santelli RV, Jacobs-Lorena M, Graessmann M, Graesmann A, Stocker A, et al. (1993) Molecular characterization of the DNA puff C-8 gene of Rhynchosciara americana. J Mol Biol 233:799-803.

Gao G, Bracken AP, Burkard K, Pasini D, Classon M, Attwooll C, Sagara M, Imai T, Helin K and Zhao J (2003) NPAT expression is regulated by E2F and is essential for cell cycle progression.Mol Cell Biol 23:2821-2833.

Gordon D, Abajian C and Green P (1998) Consed: A graphical tool for sequence finishing. Genome Res 8:195-202.

Hankeln T and Schmidt ER (1991) The organization, localization and nucleotide sequence of the histone genes of the midge Chironomus thummi. Chromosoma 101:25-31.

Kremer H and Hennig W (1990) Isolation and characterization of a Drosophila hydei histone DNA repeat unit. Nucleic Acids Res 18:1573-1580.

Lindner HH (2008) Analysis of histones, histone variants, and their post-translationally modified forms. Electrophoresis 29:2516-2532.

Machado-Santelli GM and Basile R (1973) Studies of DNA puff development in Rhynchosciara. Genetics 74:168.

Machado-Santelli GM and Basile R (1975) DNA replication and DNA puffs in salivary chromosomes of Rhynchosciara. Ciênc Cult 27:2.

Manley JL and Takagaki Y (1996) The end of the message - Another link between yeast and mammals. Science 274:14811482.

Marzluff WF (2005) Metazoan replication-dependent histone mRNAs: A distinct set of RNA polymerase II transcripts. Curr Opin Cell Biol 17:274-280.

Matsuo Y and Yamazaki T (1989) Nucleotide variation and divergence in the histone multigene family in Drosophila melanogaster. Genetics 122:87-97.

Matsuo Y (2003) Evolution of the GC content of the histone 3 gene in seven Drosophila species. Genes Genet Syst 78:309-318.

Mowry KL and Steitz JA (1987) Both conserved signals on mammalian histone pre-mRNAs associate with small nuclear 
ribonucleoproteins during 3' end formation in vitro. Mol Cell Biol 7:1663-1672.

Nagel S and Grossbach U (2000) Histone H1 genes and histone gene clusters in the genus Drosophila. J Mol Evol 51:286298.

Nagoda N, Fukuda A, Nakashima Y and Matsuo Y (2005) Molecular characterization and evolution of the repeating units of histone genes in Drosophila americana: Coexistence of quartet and quintet units in a genome. Insect Mol Biol 14:713-717.

Nonato E and Pavan C (1951) A new species of Rhynchosciara Rubsaamen, 1894 (Diptera, Mycetophilidae). Rev Bras Biol 11:435-437.

Park YJ and Luger K (2008) Histone chaperones in nucleosome eviction and histone exchange. Curr Opin Struct Biol 18:282-289.

Penalva LOF, Yokozawa J, Stocker AJ, Soares MA, Graessmann M, Orlando TC, Winter CE, Botella LM, Graessmann A and lara FJ (1997) Molecular characterization of the C-3 DNA puff gene of Rhynchosciara americana. Gene 193:163-172.

Pfaffl MW (2001) A new mathematical model for relative quantification in real-time RT-PCR. Nucleic Acids Res 29:e45.

Reese MG (2001) Application of a time-delay neural network to promoter annotation in the Drosophila melanogaster genome. Comput Chem 26:51-56.

Rezende-Teixeira P, Siviero F, da Costa Rosa M and MachadoSantelli GM (2009) The R2 mobile element of Rhynchosciara americana: Molecular, cytological and dynamic aspects. Chromosome Res 17:455-467.

Rezende-Teixeira P, Palomino NB and Machado-Santelli GM (2012) Rananos expression pattern during oogenesis and early embryonic development in Rhynchosciara americana. Dev Genes Evol 222:153-164.

Rice P, Longden I and Bleasby A (2000) EMBOSS: The European Molecular Biology Open Software Suite. Trends Genet 16:276-277.

Rudkin GT and Corlette, SL (1957) Disproportionate synthesis of DNA in a polytene chromosome region. Proc Natl Acad Sci U S A 43:964-968.

Santelli RV, Cattapan LDN and Machado-Santelli GM (1996) Cloning of the histone gene repeat of Rhynchosciara americana. Ciênc Cult 48:313-316.

Santelli RV, Machado-Santelli GM, Pueyo MT, Navarro-Cattapan LD and Lara FJ (1991) Replication and transcription in the course of DNA amplification of the C3 and C8 DNA puffs of Rhynchosciara americana. Mech Dev 36:59-66.

Santelli RV, Siviero F, Machado-Santelli GM, Lara FJS and Stocker AJ (2004) Molecular characterization of the B-2 DNA puff gene of Rhynchosciara americana. Chromosoma 113:167-176.

Siviero F, Rezende-Teixeira P, Andrade A, Machado-Santelli GM and Santelli RV (2006) Analysis of expressed sequence tags from Rhynchosciara americana salivary glands. Insect Mol Biol 15:109-118.

Soldati D and Schümperli D (1988) Structural and functional characterization of mouse U7 small nuclear RNA active in 3 ' processing of histone pre-mRNA. Mol Cell Biol 8:15181524.

Stocker AJ and Gorab E (2000) The chromosomes of Rhynchosciara baschanti (Diptera: Sciaridae): Molecular cytogenetic comparisons with taxa in the americana-like group. Genome 43:786-795.

Thatcher TH and Gorovsky MA (1994) Phylogenetic analysis of the core histones H2A, H2B, H3, and H4. Nucleic Acids Res 22:174-179.

Thompson JD, Gibson TJ, Plewniak F, Jeanmougin F and Higgins DJ (1997) The CLUSTAL_X windows interface: Flexible strategies for multiple sequence alignment aided by quality analysis tools. Nucleic Acids Res 25:4876-4882.

Zhao J, Kenned YBK, Lawrence BD, Barbie DA, Matera AG, Fletcher JA and Harlow E (2000) NPAT links cyclin E$\mathrm{Cdk} 2$ to the regulation of replication-dependent histone gene transcription. Genes Dev 14:2283-2297.

\section{Internet resources}

Peden JF (1999) Analysis of codon usage. PhD Thesis, University of Nottingham, UK, http://codonw.sourceforge.net/index.html (accessed February 19, 2014).

\section{Supplementary material}

The following online material is available for this article: Table S1 - Nucleotide base distribution in the $3^{\text {rd }}$ codon position and GC content of the coding region and in the $3^{\text {rd }}$ codon base. (codon Bias Index).

Table S2 - Codon usage for Rhynchosciara americana Histone $\mathrm{H} 1$.

Table S3 - Codon usage for Rhynchosciara americana Histone $\mathrm{H} 3$.

Table S4 - Codon usage for Rhynchosciara americana Histone H2A.

Table S5 - Codon usage for Rhynchosciara americana Histone H2B.

Table S6 - Codon usage for Rhynchosciara americana Histone $\mathrm{H} 4$.

Table S7 - Average codon usage for Rhynchosciara americana histone genes.

Associate Editor: Igor Schneider

License information: This is an open-access article distributed under the terms of the Creative Commons Attribution License (type CC-BY), which permits unrestricted use, distribution and reproduction in any medium, provided the original article is properly cited. 